\title{
Barrier Animal Facility Shared Resource
}

National Cancer Institute

\section{Source}

National Cancer Institute. Barrier Animal Facility Shared Resource. NCI Thesaurus. Code C39329.

The Animal Barrier Shared Resource provides for acquisition and maintenance of both pathogen-free and infected laboratory animals, including immunodeficient strains, while permitting supervised access for investigators, stable husbandry conditions, and individualized daily health care for animals. The Resource implements methods that allow maximal retention of animals when an infectious agent is detected in a barrier room. These include static microisolator housing, handling animals with disinfected forceps, opening animal cages only in a hood, cage-by-cage testing and requiring that full barrier garb be worn by all persons entering animal rooms. 